\section{Re-wilding: introductions could reduce biodiversity}

SIR - The Commentary article by Josh Donlan and colleagues (" $\mathrm{Re}$-wilding North America" Nature 436, 913-914; 2005) argues for the introduction of old-world mammals to North America, on the grounds that these are proxies for megafauna that lived there at the end of the Pleistocene. This perspective overlooks environmental changes that have occurred during the intervening millennia, and that have produced qualitatively different communities in new ecological equilibria.

For example, global dimate change since the Pleistocene extinctions makes the restoration of vanished ecosystems through large-mammal introduction quite unlikely. Such environmental change also increases the risk that introduced species might respond in unexpected ways. Indeed, one of the reintroductions proposed by Donlan and colleagues - the camel - was previously attempted during the nineteenth century (T. L. Connelly, Southwestern Historical Quarterly69, 442-462; 1966). At that time, camels seemed an ideal beast of burden for use in the North American arid regions, but American environments ultimately proved inhospitable. By 1900, both public and private introduction programmes had failed, and the remaining feral camels had died.

The inherent unpredictability associated with disturbing ecosystems means that, while some introductions might follow the camel's fate, others might prove all too capable of adapting to contemporary North American environments, potentially at the expense of other species of conservation value. Indeed, introduced species are now a major cause of biodiversity losses worldwide.

Christopher Irwin Smith

Department of Biological Sciences,

University of Idaho, Moscow, Idaho 83844, USA

\section{Re-wilding: other projects help carnivores stay wild}

SIR - In their plea for bringing Pleistocene wildlife to the New World ( ${ }^{\circ} \mathrm{Re}$-wilding North America" Nature 436, 913-914; 2005), Josh Donlan and colleagues do not discuss successful efforts to ensure long-term survival oflarge carnivores in Africa and Asia.

In Namibia, the Cheetah Conservation Fund has developed programmes to foster acceptance of this predator, by providing farmland-owners with educational material and encouraging them to take pride in cheetah presence. The number of cheetahs removed has dropped from 19 to 2.1 per farm per year since 1991. Ranchers enrolled in the programme can also export beef, certified 'cheetah friendly', to the European Union - making cheetah protection both ecologically possible and economically profitable.

In Kenya, a study shows that bomas, traditional corrals with thick walls and internal rooms, are effective at reducing the amount of livestock killed by lions (M. O. Ogada et al. Conserv. Biol 17, 1521-1530; 2003). This finding has the potential to reduce conflict with humans, which is the main threat to lion survival.

In central Asia, the International Snow Leopard Trust and the Snow Leopard Conservancy provide incentives to local herders for protecting snow leopards. These include insurance against damage by carnivores, veterinary care for livestock and income generation from handicrafts. Participating herders in Mongolia, the Kyrgyz Republic and Pakistan agree not to kill snow leopards or their prey, in exchange for access to foreign markets to sell labelled knitwear.

The success of this programme owes much to peer pressure, as the whole community loses the bonus if one person violates the contract. In the eastern Kyrgyz Republic, this has led to the first year with no recorded poaching since the collapse of the Soviet Union.

We believe that these diverse pilot schemes will ensure that large carnivores in Africa and Asia have a good chance of persisting in the wild into the next century.

Guillaume Chapron

Laboratoire d'Ecologie CNRS UMR 7625 et

Plateforme Ervironnement, Ecole Normale Supérieure, 24 rue Lhomond, 75005 Paris, France Laboratoire d'Ecologie Animale UMR MA105, Université d'Angers, France

\section{Malaysia can't thrive while it excludes minority talent}

SIR - As a Chinese Malaysian, I sympathize with the sentiments described in your News story "The Valley of Ghosts" (Nature 436, 620-621;2005) about the Malaysian government's often-denied 'Malays first' policy. In particular, university admissions are suspicious. Malay admissions are based on results from exams called Matrikulasi, taken at Malay-only pre-university colleges, whereas other students have to take the national Malaysian Higher School Certificate (STPM) exam. Reports of ethnic-minority students with near-perfect STPM results not getting a place at the local university have become the norm, and yet objections are often ignored - the government claims that it's a fair game for all.

Personally, I had no choice but to go overseas to study, and my parents had to spend their entire pension savings on financing my undergraduate degree in Australia. After graduation, most of my Malaysian classmates chose to either stay in Australia or work in Singapore, where fair competition and equal opportunities give them better job prospects. Before coming to the Netherlands I did my master's degree in Singapore, where I met many Chinese Malaysians in this situation.

Most of us would like to return to Malaysia, but we know that research prospects for minorities are limited. No matter how talented we are, it seems we still have to travel outside our country to seek opportunities. In Yee Phang

Department of Materials Science and Technology of Polymers, University of Twente, PO Box 217,7500 AE Enschede, The Netherlands

\section{Harry Potter and the prisoner of presumption}

SIR - Jeffrey Craig and colleagues, in Correspondence ( ${ }^{\circ} \mathrm{Harry}$ Potter and the recessive allele Nature 436, 776; 2005), recommend the use of analogies as tools for introducing young people to scientific concepts. Taking their example from

J. K. Rowling's stories about the young wizard Harry Potter, they suggest that wizarding is a monogenic trait, with the wizard allele $(W)$ recessive to the muggle allele $(M)$. We believe the assumption that wizarding has a genetic basis to be deterministic and unsupported by available evidence.

Following Craig and colleagues' analogy, Hermione, as a muggle-born witch, must have WM parents. However, as Rowling fans could point out, Hermione's parents were muggle dentists who lack any family history of wizarding. It's true, of course, that chance may not have thrown up a witch or wizard for many generations, or that any who did have magical powers may have kept them secret to avoid a witch hunt.

What about Neville's apparently poor wizarding skills? These cannot be explained by incomplete penetrance, as Craig and colleagues suggest. In incomplete penetrance, individuals either display the trait or not: they do not display an intermediate degree of the trait. Poor wizarding skills might be indicative of variable expressivity of an allele. However, both variable expressivity and incomplete penetrance are associated with dominant alleles. If the wizarding allele were dominant, rather than recessive as suggested, wizarding children such as Hermione could not be born to non-wizarding parents.

Neville's clumsiness may, perhaps, be an individual characteristic unrelated to his potential powers. However, it is not possible, from the evidence presented so far, to conclude that wizarding is a heritable trait.

Antony N. Dodd, Carlos T. Hotta,

Michael J. Gardner

Department of PlantSciences,

University of Cambridge, Downing Street, Cambridge CB2 3EA, UK 